\title{
Performance and Economics of Sweet Corn as Influenced by Leafy Vegetables Intercropping System under Protective Irrigated Condition
}

\author{
R. Vidhyashree ${ }^{*}$, M.B. Patil ${ }^{1}$, A.K. Guggari ${ }^{1}$ and A.P. Biradar ${ }^{2}$ \\ ${ }^{1}$ Department of Agronomy, College of Agriculture, Vijayapura-586108, India \\ ${ }^{2}$ Department of Agricultural Entomology, College of Agriculture, Vijayapura-586108, India \\ *Corresponding author
}

\section{A B S T R A C T}

\begin{tabular}{|l|}
\hline Ke y w o r d s \\
Sweet corn, \\
Intercropping \\
system, Growth, \\
Yield, Economics \\
\hline Article Info \\
\hline Accepted: \\
07 July 2019 \\
Available Online: \\
10 August 2019 \\
\hline
\end{tabular}

The present investigation was undertaken during Kharif 2018 at the college of Agriculture, Vijayapura, University of Agricultural Sciences, Dharwad (Karnataka). The objective of this study was to study the effect of different vegetables intercrops on growth, yield and economics of sweet corn and vegetable intercropping systems. The experiment was laid out in Randomized Block Design with three replications and ten treatments. These ten treatments comprised of sweet corn as a base crop and fenugreek, spinach, Amaranthus and dill as intercrops. The sole sweet corn $(90 \mathrm{~cm} \times 20 \mathrm{~cm})$ recorded significantly higher growth parameters namely leaf area and LAI at different phenological stages. Significantly higher fresh cob yield $\left(184 \mathrm{q} \mathrm{ha}^{-1}\right)$ and green fodder yield $\left(295 \mathrm{q} \mathrm{ha}^{-1}\right)$ was recorded by sole sweet corn $(90 \mathrm{~cm} \times 20 \mathrm{~cm})$. The increase in fresh cob yield and green fodder yield with sole sweet corn $(90 \mathrm{~cm} \times 20 \mathrm{~cm})$ could be the maximum length of cob $(24.30 \mathrm{~cm})$, girth of cob $(10.73 \mathrm{~cm})$, cob weight $(403.33 \mathrm{~g} / \mathrm{cob})$ and number of kernels per cob (597) over the rest of the treatments. The Sweet corn $(90 \mathrm{~cm} \times 20 \mathrm{~cm})+$ fenugreek intercropping system in 1:2 row proportion was the most remunerative with net returns ( $₹ 328178 \mathrm{ha}^{-1}$ ) and B: C (8.67) over the rest of the intercropping systems.

\section{Introduction}

Sweet corn is one of the most popular types for human consumption among different types of corn grown. It is peculiarly an American crop. Origin of sweet corn is considered as Peru, Bolivia and Equador. Sweet corn has been bred to have higher levels of natural sugar, which makes it very popular. It is hybridized maize, specially bred to increase sugar content and also known as "sugar corn". Vegetable as an intercrop provides leafy vegetable under rainfed situation within short duration which gives more monetary returns than any other short duration agronomical crop as demand of vegetables during the rainy season is more. Fenugreek commonly known as methi is cultivated throughout India which is used for cooking, salad and fodder purpose. Spinach is one of the most common vegetables of tropical and subtropical region and is grown widely in India. Leaves are rich in vitamin $\mathrm{A}, \mathrm{C}$, calcium, etc. coriander is used as common flavouring substance. Its leaves are used for flavouring curries, sauces and soups. Garlic leaves are rich in proteins, 
phosphorus, potassium, calcium, magnesium, carbohydrates and used for cooking purpose. Intercropping is a type of mixed cropping and defined the agricultural practice of cultivating two or more crops in the same space at the same time (Andrew and Kassam, 1976). Intercropping is much more scientific, rational and refined concept than traditional practice of mixed cropping. Although intercropping is not now new concept it has attracted worldwide attention due to its various advantages. It was originally practiced as an insurance against crop failure under rainfed conditions. Risk may be minimized in intercropping (Woolley and Davis, 1991). Biological efficiency of intercropping due to exploration of large soil mass compared to monocropping (Francis, 1989). This advanced agrotechnique has been practiced in past decades and achieved the goal of agriculture. There are some socioeconomic (Ofori and Stern, 1987), biological and ecological advantages (Fininsa, 1996) in intercroping over monocropping. Several scientists have been worked with intercropping (Brintha and Seran, 2009). At present its main objective is higher productivity per unit area in addition to stability in production in rainfed situation where uncertainly and ill distribution of rainfall, monocropping becomes risky. By considering the detail study, present investigation was planned with objectives as to study the effect of different vegetables intercrops on growth, yield and economics of sweet corn and vegetable intercropping systems

\section{Materials and Methods}

A Field experiment was conducted during kharif 2018 at College of Agriculture, Vijayapura, University of Agricultural Sciences, Dharwad (Karnataka). It is located in Vijayapura district in the northern part of Karnataka State at $16^{\circ} 49^{\prime}$ North latitude, $75^{\circ}$ 43' East longitude and at an altitude of 593.8 $\mathrm{m}$ above the mean sea level. The topography of the experiment plot was uniform. The selection of site was considered on the basis of suitability of the land for cultivation of sweet corn and different intercrops. The field experiment was laid out in Randomized block design comprising of ten treatments replicated thrice viz., $\mathrm{T}_{1}$ : Sole sweet corn $(60 \mathrm{~cm} \times 20$ $\mathrm{cm}), \mathrm{T}_{2}$ : Sole sweet corn $(90 \mathrm{~cm} \times 20 \mathrm{~cm}), \mathrm{T}_{3}$ : Sweet corn $(60 \mathrm{~cm} \times 20 \mathrm{~cm})+\operatorname{dill}(1: 1), \mathrm{T}_{4}$ : Sweet corn $(60 \mathrm{~cm} \times 20 \mathrm{~cm})+\operatorname{spinach}(1: 1)$, $\mathrm{T}_{5}$ : Sweet corn $(60 \mathrm{~cm} \times 20 \mathrm{~cm})+$ amaranthus (1:1), $\mathrm{T}_{6:}$ Sweet corn $(60 \mathrm{~cm} \times 20 \mathrm{~cm})+$ fenugreek (1:1), $\mathrm{T}_{7}$ : Sweet corn $(90 \mathrm{~cm} \times 20$ $\mathrm{cm})+\operatorname{dill}(1: 2), \mathrm{T}_{8}:$ Sweet corn $(90 \mathrm{~cm} \times 20$ $\mathrm{cm})+\operatorname{spinach}(1: 2), \mathrm{T}_{9}$ : Sweet corn $(90 \mathrm{~cm} \times$ $20 \mathrm{~cm})+$ amaranthus (1:2), $\mathrm{T}_{10}$ : Sweet corn $(90 \mathrm{~cm} \times 20 \mathrm{~cm})+$ fenugreek $(1: 2)$. Soil of the experimental site was clayey in texture, slightly alkaline in nature having moderate organic carbon content, low available nitrogen, medium available phosphorus and high available potassium.

\section{Results and Discussion}

\section{Growth attributes}

Photosynthetic parameters like leaf area and leaf area index differed significantly at all growth stages of sweet corn intercropped with leafy vegetables. The sole sweet corn $(90 \mathrm{~cm}$ $\times 20 \mathrm{~cm}$ ) registered with significantly higher leaf area $\left(7.95,29.94\right.$ and $81.11 \mathrm{dm}^{2}$ at 20, 40 and $60 \mathrm{DAS}$, respectively) as compared to sweet corn $(60 \mathrm{~cm} \times 20 \mathrm{~cm})+$ spinach $(1: 1)$ intercropping system which was recorded significantly lower leaf area (3.47, 13.92 and $38.39 \mathrm{dm}^{2}$ at 20, 40 and 60 DAS, respectively) (Table 1). With respect to leaf area index the sole sweet corn $(60 \mathrm{~cm} \times 20 \mathrm{~cm})$ which recorded the higher leaf area index $(0.43,1.69$ and 4.71 at 20,40 and 60 DAS, respectively) as compared to sweet corn $(60 \mathrm{~cm} \times 20 \mathrm{~cm})+$ spinach (1:1) intercropping system $(0.29,1.16$ and 3.20 at 20, 40 and $60 \mathrm{DAS}$, respectively) 
(Table 2). These results corroborate the findings of Hossain et al., (2015) and Chaudhari et al., (2018). Plant canopies intercept light with varying degrees of efficiency associated chiefly with the LAI. The efficiency of intercepting of incident light, combined with efficiency of photochemical reactions of the leaves determine the efficiency of the canopy in utilizing radiation energy per unit of land area.

\section{Yield and yield attributes}

The present study revealed that, sole sweet corn sown at $90 \mathrm{~cm} \times 20 \mathrm{~cm}$ spacing recorded significantly higher fresh cob yield (184 $\mathrm{q} \mathrm{ha} \mathrm{h}^{-1}$ ) over the rest of the treatments. The increase in fresh cob yield was 50.5 percent over the intercropping of spinach at 1:1 row proportion with sweet corn sown at $60 \mathrm{~cm}$ inter row spacing (Table 3). The increment in the fresh cob yield of sweet corn was due to higher yield attributing characteristics viz., cob length, cob girth, cob weight and number of kernels per cob, these results are in line with the findings of Hossain et al., (2015).

Significantly higher green fodder yield $(295 \mathrm{q}$ $\left.\mathrm{ha}^{-1}\right)$ was recorded in sole sweet corn $(90 \mathrm{~cm} \times$ $20 \mathrm{~cm}$ ) over the rest of the treatments. The increase in green fodder yield with sole sweet corn $(90 \mathrm{~cm} \times 20 \mathrm{~cm})$ was 46.5 per cent over the intercropping of spinach at 1:1 row proportion with sweet corn sown at $60 \mathrm{~cm}$ interrow spacing (Table 4 and Fig. 1).

The higher fresh cob yield and green fodder yield of sweet corn was mainly due to no biological competition for basic resources, exerted by the component crop in the sole crop for the growth resources during various stages of the crop growth and which leads to better translocation of photosynthates from source to sink and higher growth attributing characters like higher number of leaves, leaf area and higher dry matter production and its accumulation into different parts of plant and yield attributing characters like cob length and girth, cob weight and number of kernels per cob. The results are in conformity with the findings of Chaudhari et al., (2018) and Hossain et al., (2015) in maize + winter vegetables intercropping with different row proportions.

The higher yield performance in sole sweet corn $(90 \mathrm{~cm} \times 20 \mathrm{~cm})$ may be due to higher values of yield attributes (Table 3), namely length of cob $(24.30 \mathrm{~cm})$, girth of cob $(10.73$ $\mathrm{cm})$, cob weight (403.33 g/cob) and number of kernels per cob (597). This may be assigned to availability of good micro climate and area availability to the crop for nourishment is high as there is no inclusion of intercrop, per unit area more vegetative and the total biological competition among each plant were minimum. Similar kinds of result are also reported by Madhu (2013) in maize and intercropping system with different row proportions.

\section{Economics}

The economic returns measure the profitability of a system. The farmers adopt only such practices that are more profitable and viable over longer period. The data on the total cost, gross income, net income and B: C as influenced by different treatments are presented in Table 5. The net returns differed significantly due to intercropping systems. Sweet corn $(90 \mathrm{~cm} \times 20 \mathrm{~cm})+$ fenugreek intercropping system in 1:2 row proportion was the most remunerative with net returns ( $₹$ $328178 \mathrm{ha}^{-1}$ ) as compared to other treatments.

The increase in net returns was 36.6 percent over the sole sweet corn $(60 \mathrm{~cm} \times 20 \mathrm{~cm})$. This is due to lower cost of cultivation and higher market price of fenugreek as compared to other intercropping systems. Similar kind of results has also been reported by Vilhekar et al., (2014) in sweet corn + leafy vegetables intercropping systems. 
Table.1 Leaf area per plant at different growth stages of sweet corn as influenced by intercropping with leafy vegetables

\begin{tabular}{|c|c|c|c|c|}
\hline \multirow[t]{2}{*}{ Treatments } & \multicolumn{4}{|c|}{ Leaf area $\left(\mathrm{dm}^{2}\right)$ per plant } \\
\hline & 20 DAS & 40 DAS & 60 DAS & At harvest \\
\hline$T_{1}$-Sole sweet corn $(60 \mathrm{~cm} \times 20 \mathrm{~cm})$ & 5.18 & 20.33 & 56.55 & 28.64 \\
\hline$T_{2}$-Sole sweet corn $(90 \mathrm{~cm} \times 20 \mathrm{~cm})$ & 7.95 & 29.94 & 81.11 & 51.82 \\
\hline$T_{3}-S w e e t$ corn $(60 \mathrm{~cm} \times 20 \mathrm{~cm})+$ Dill $(1: 1)$ & 4.47 & 17.40 & 48.12 & 23.11 \\
\hline$T_{4}$-Sweet corn $(60 \mathrm{~cm} \times 20 \mathrm{~cm})+$ Spinach $(1: 1)$ & 3.47 & 13.92 & 38.39 & 17.40 \\
\hline$T_{5}-$ Sweet corn $(60 \mathrm{~cm} \times 20 \mathrm{~cm})+$ Amaranthus $(1: 1)$ & 4.02 & 15.67 & 45.72 & 21.26 \\
\hline$T_{6}$-Sweet corn $(60 \mathrm{~cm} \times 20 \mathrm{~cm})+$ Fenugreek $(1: 1)$ & 4.73 & 18.43 & 52.02 & 27.28 \\
\hline$T_{7}-S w e e t$ corn $(90 \mathrm{~cm} \times 20 \mathrm{~cm})+$ Dill $(1: 2)$ & 6.50 & 24.13 & 65.21 & 37.75 \\
\hline$T_{8}-$ Sweet corn $(90 \mathrm{~cm} \times 20 \mathrm{~cm})+$ Spinach $(1: 2)$ & 5.28 & 21.49 & 59.22 & 31.31 \\
\hline$T_{9}-$ Sweet corn $(90 \mathrm{~cm} \times 20 \mathrm{~cm})+$ Amaranthus $(1: 2)$ & 5.78 & 23.69 & 61.52 & 32.93 \\
\hline$T_{10}-S w e e t$ corn $(90 \mathrm{~cm} \times 20 \mathrm{~cm})+$ Fenugreek $(1: 2)$ & 6.90 & 25.29 & 69.54 & 40.88 \\
\hline S.Em. \pm & 0.60 & 1.56 & 3.39 & 1.86 \\
\hline C.D. $(P=0.05)$ & 1.81 & 4.74 & 10.27 & 5.64 \\
\hline
\end{tabular}

Table. 2 Leaf area index at different growth stages of sweet corn as influenced by intercropping with leafy vegetables

\begin{tabular}{|c|c|c|c|c|}
\hline \multirow[t]{2}{*}{ Treatments } & \multicolumn{4}{|c|}{ Leaf area Index } \\
\hline & 20 DAS & 40 DAS & 60 DAS & At harvest \\
\hline$T_{1}$-Sole sweet corn $(60 \mathrm{~cm} \times 20 \mathrm{~cm})$ & 0.43 & 1.69 & 4.71 & 2.87 \\
\hline$T_{2}$-Sole sweet corn $(90 \mathrm{~cm} \times 20 \mathrm{~cm})$ & 0.44 & 1.66 & 4.51 & 2.38 \\
\hline$T_{3}-$ Sweet corn $(60 \mathrm{~cm} \times 20 \mathrm{~cm})+$ Dill $(1: 1)$ & 0.37 & 1.45 & 4.07 & 1.93 \\
\hline$T_{4}-S w e e t$ corn $(60 \mathrm{~cm} \times 20 \mathrm{~cm})+$ Spinach $(1: 1)$ & 0.29 & 1.16 & 3.20 & 1.45 \\
\hline$T_{5}$-Sweet corn $(60 \mathrm{~cm} \times 20 \mathrm{~cm})+$ Amaranthus $(1: 1)$ & 0.33 & 1.28 & 3.81 & 1.77 \\
\hline$T_{6}$-Sweet corn $(60 \mathrm{~cm} \times 20 \mathrm{~cm})+$ Fenugreek $(1: 1)$ & 0.39 & 1.54 & 4.33 & 2.27 \\
\hline$T_{7}-$ Sweet corn $(90 \mathrm{~cm} \times 20 \mathrm{~cm})+$ Dill $(1: 2)$ & 0.36 & 1.34 & 3.62 & 2.10 \\
\hline$T_{8}-S w e e t$ corn $(90 \mathrm{~cm} \times 20 \mathrm{~cm})+\operatorname{Spinach}(1: 2)$ & 0.29 & 1.19 & 3.25 & 1.74 \\
\hline$T_{9}$-Sweet corn $(90 \mathrm{~cm} \times 20 \mathrm{~cm})+$ Amaranthus $(1: 2)$ & 0.32 & 1.32 & 3.42 & 1.83 \\
\hline$T_{10}-$ Sweet corn $(90 \mathrm{~cm} \times 20 \mathrm{~cm})+$ Fenugreek $(1: 2)$ & 0.38 & 1.42 & 3.86 & 2.27 \\
\hline S.Em. \pm & 0.03 & 0.08 & 0.20 & 0.17 \\
\hline C.D. $(P=0.05)$ & 0.09 & 0.26 & 0.61 & 0.52 \\
\hline
\end{tabular}


Table.3 Yield attributes of sweet corn as influenced by intercropping with leafy vegetables

\begin{tabular}{|c|c|c|c|c|}
\hline \multirow[t]{2}{*}{ Treatments } & \multicolumn{4}{|c|}{ Yield attributes of sweet corn } \\
\hline & Cob length $(\mathrm{cm})$ & Cob girth $(\mathrm{cm})$ & Cob weight $\left(\mathrm{g} \mathrm{cob}^{-1}\right)$ & $\begin{array}{c}\text { Number of kernels } \\
\text { per cob }\end{array}$ \\
\hline$T_{1}$-Sole sweet corn $(60 \mathrm{~cm} \times 20 \mathrm{~cm})$ & 20.27 & 8.83 & 351.67 & 557.00 \\
\hline$T_{2}$-Sole sweet corn $(90 \mathrm{~cm} \times 20 \mathrm{~cm})$ & 24.30 & 10.73 & 403.33 & 597.00 \\
\hline$T_{3}-S w e e t$ corn $(60 \mathrm{~cm} \times 20 \mathrm{~cm})+\operatorname{Dill}(1: 1)$ & 19.37 & 8.17 & 335.33 & 534.33 \\
\hline$T_{4}-S w e e t$ corn $(60 \mathrm{~cm} \times 20 \mathrm{~cm})+$ Spinach $(1: 1)$ & 17.34 & 7.40 & 321.33 & 509.00 \\
\hline$T_{5}-$ Sweet corn $(60 \mathrm{~cm} \times 20 \mathrm{~cm})+$ Amaranthus $(1: 1)$ & 18.87 & 7.73 & 330.67 & 525.67 \\
\hline$T_{6}-$ Sweet corn $(60 \mathrm{~cm} \times 20 \mathrm{~cm})+$ Fenugreek $(1: 1)$ & 20.00 & 8.47 & 341.33 & 546.33 \\
\hline$T_{7}-$ Sweet corn $(90 \mathrm{~cm} \times 20 \mathrm{~cm})+$ Dill $(1: 2)$ & 23.43 & 10.33 & 382.00 & 578.33 \\
\hline$T_{8}-$ Sweet corn $(90 \mathrm{~cm} \times 20 \mathrm{~cm})+\operatorname{Spinach}(1: 2)$ & 21.00 & 9.63 & 362.00 & 568.33 \\
\hline$T_{9}-S w e e t$ corn $(90 \mathrm{~cm} \times 20 \mathrm{~cm})+$ Amaranthus $(1: 2)$ & 22.97 & 10.00 & 370.67 & 570.33 \\
\hline$T_{10}$-Sweet corn $(90 \mathrm{~cm} \times 20 \mathrm{~cm})+$ Fenugreek $(1: 2)$ & 23.83 & 10.40 & 392.00 & 588.33 \\
\hline S.Em. \pm & 1.29 & 0.73 & 17.46 & 17.91 \\
\hline C.D. $(P=0.05)$ & 3.92 & 2.20 & 52.97 & 54.34 \\
\hline
\end{tabular}

Table.4 Fresh cob yield, green fodder yield and harvest index of sweet corn as influenced by intercropping with leafy vegetables

\begin{tabular}{|c|c|c|c|}
\hline Treatments & Fresh cob yield $\left(\mathrm{q} \mathrm{ha}^{-1}\right)$ & Green fodder yield $\left(q\right.$ ha $\left.^{-1}\right)$ & Harvest index (\%) \\
\hline$T_{1}$-Sole sweet corn $(60 \mathrm{~cm} \times 20 \mathrm{~cm})$ & 131 & 198 & 39.8 \\
\hline$T_{2}$-Sole sweet corn $(90 \mathrm{~cm} \times 20 \mathrm{~cm})$ & 184 & 295 & 38.4 \\
\hline$T_{3}$-Sweet corn $(60 \mathrm{~cm} \times 20 \mathrm{~cm})+\operatorname{Dill}(1: 1)$ & 126 & 188 & 40.5 \\
\hline$T_{4}-$ Sweet corn $(60 \mathrm{~cm} \times 20 \mathrm{~cm})+$ Spinach $(1: 1)$ & 93 & 137 & 38.7 \\
\hline$T_{5}-$ Sweet corn $(60 \mathrm{~cm} \times 20 \mathrm{~cm})+$ Amaranthus $(1: 1)$ & 116 & 177 & 40.4 \\
\hline$T_{6}-$ Sweet corn $(60 \mathrm{~cm} \times 20 \mathrm{~cm})+$ Fenugreek $(1: 1)$ & 128 & 197 & 37.4 \\
\hline$T_{7}-$ Sweet corn $(90 \mathrm{~cm} \times 20 \mathrm{~cm})+\operatorname{Dill}(1: 2)$ & 161 & 235 & 40.8 \\
\hline$T_{8}-S w e e t$ corn $(90 \mathrm{~cm} \times 20 \mathrm{~cm})+\operatorname{Spinach}(1: 2)$ & 141 & 210 & 40.5 \\
\hline$T_{9}$-Sweet corn $(90 \mathrm{~cm} \times 20 \mathrm{~cm})+$ Amaranthus $(1: 2)$ & 150 & 222 & 40.5 \\
\hline$T_{10}-$ Sweet corn $(90 \mathrm{~cm} \times 20 \mathrm{~cm})+$ Fenugreek $(1: 2)$ & 169 & 255 & 39.8 \\
\hline S.Em. \pm & 17 & 23 & 3.51 \\
\hline C.D. $(P=0.05)$ & 52 & 71 & NS \\
\hline
\end{tabular}


Table.5 Economic evaluation of sweet corn based intercropping system

\begin{tabular}{|c|c|c|c|}
\hline Treatments & Gross returns (₹ ha-1) & Net returns $\left(₹\right.$ ha $\left.^{-1}\right)$ & $\mathrm{B}: \mathrm{C}$ \\
\hline$T_{1}-$ Sole sweet corn $(60 \mathrm{~cm} \times 20 \mathrm{~cm})$ & 151227 & 107859 & 3.49 \\
\hline$T_{2}$-Sole sweet corn $(90 \mathrm{~cm} \times 20 \mathrm{~cm})$ & 253714 & 216562 & 6.83 \\
\hline$T_{3}-$ Sweet corn $(60 \mathrm{~cm} \times 20 \mathrm{~cm})+\operatorname{Dill}(1: 1)$ & 223504 & 176079 & 4.71 \\
\hline$T_{4}-S w e e t$ corn $(60 \mathrm{~cm} \times 20 \mathrm{~cm})+$ Spinach $(1: 1)$ & 280823 & 230293 & 5.56 \\
\hline$T_{5}-$ Sweet corn $(60 \mathrm{~cm} \times 20 \mathrm{~cm})+$ Amaranthus $(1: 1)$ & 284968 & 235959 & 5.81 \\
\hline$T_{6}-S w e e t$ corn $(60 \mathrm{~cm} \times 20 \mathrm{~cm})+$ Fenugreek $(1: 1)$ & 282678 & 234254 & 5.84 \\
\hline$T_{7}-S w e e t$ corn $(90 \mathrm{~cm} \times 20 \mathrm{~cm})+$ Dill $(1: 2)$ & 306965 & 265397 & 7.38 \\
\hline$T_{8}-S w e e t$ corn $(90 \mathrm{~cm} \times 20 \mathrm{~cm})+\operatorname{Spinach}(1: 2)$ & 339204 & 293823 & 7.47 \\
\hline 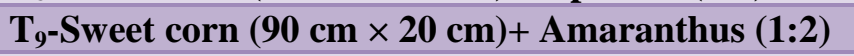 & 329428 & 285919 & 7.57 \\
\hline$T_{10}-$ Sweet corn $(90 \mathrm{~cm} \times 20 \mathrm{~cm})+$ Fenugreek $(1: 2)$ & 370968 & 328178 & 8.67 \\
\hline S.Em. \pm & 16746 & 16746 & 0.35 \\
\hline C.D. $(P=0.05)$ & 50799 & 50799 & 1.07 \\
\hline
\end{tabular}

Fig.1 Fresh cob yield, green fodder yield and harvest index of sweet corn as influenced by intercropping with leafy vegetables

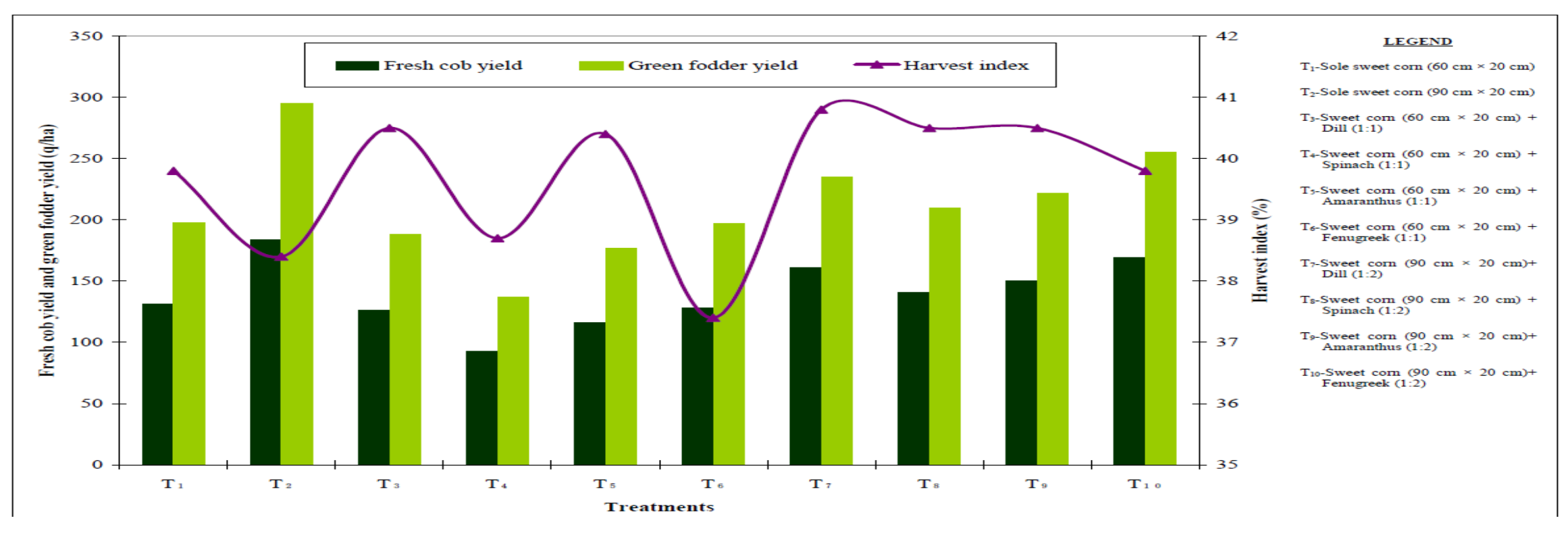


Among all the intercropping systems, sweet corn $(90 \mathrm{~cm} \times 20 \mathrm{~cm})+$ fenugreek $(8.67)$ recorded significantly higher $\mathrm{B}: \mathrm{C}$ than the sole sweet corn $(60 \mathrm{~cm} \times 20 \mathrm{~cm})$ which recorded significantly lower B: C (3.49) (Table 5). The increase in the B: $\mathrm{C}$ was 44.3 percent over the sole sweet corn $(60 \mathrm{~cm} \times 20$ $\mathrm{cm})$. This was mainly due to the lower cost of cultivation incurred and higher gross returns realised, compared to other treatments. Similar results of higher B: C was reported by Mian et al., (2011) in maize + leafy vegetables intercropping system.

\section{References}

Andrew, D. J. and Kassam, A. H. 1976. The importance of multiple cropping in increasing world food supplies. In: Multiple cropping, Papendick, R.I., Sanchez, A. and Triplett, G.B. (Eds.) American Society Agronomy, Madison, WI, U.S.A.

Brintha, I. and Seran, T. H. 2009. Effect of paired row planting of radish (Raphonus sativus L.) intercropped with vegetable amaranths (Amaranths tricolor L.) on yield components of radish in sandy regosol. J. Agric. Sci., 4 (1): 19-28.

Chaudhari, K. D., Rajemahadik, V. A., Chaval, V.G., More, V. G. and Chavan, A. P. 2018. Intercropping of different leafy vegetables under paired row planted sweet corn in lateritic soils of Maharashtra state. Intl. J. Agric. Sci., 10(8): 5834-5837.

Fininsa, C. 1996. Effect of bean and maize intercropping on bean common bacterial blight and rust diseases. Internat. J. Pest
Mgmt., 42 (1): 51-54.

Francis, C. A. 1989. Biological efficiency in multiple cropping systems. Adv. Agro., 42: $1-42$.

Hossain, M. H., Shamal Kumar, Bhowal, A. S. M. and Khan, M. R. 2015. Intercropping System of Maize with Different Winter Vegetables. Malays. $J$. Med. Biol. Res., 2(2): 153-156.

Madhu, 2013. Response of maize (Zea mays L.) nutrient management for maximization of productivity in maize (Zea mays L.) and field bean (Dolichos lablab L.) intercropping system. M. Sc. (Agri.) Thesis, Univ. Agric. Sci., Bengaluru, Karnataka (India).

Mian, M. A. K., Alam, M. S. and Hossain, J. 2011. Weed growth, yield and economics of maize + spinach intercropping. Bangladesh J. Weed Sci. 2(1-2): 41-46.

Ofori, F. and Stern, W. R. 1987. Cereal legume intercropping systems. $A d v$. Agron., 41: 41-90.

Vilhekar, S. C., Badole, K. K. and Ghanbahadur, M. R. 2014. Performance and economics of sweet corn as influenced by leafy vegetables intercropping system under rainfed condition. Adv. Res. J. Crop Improv., 5(2): 118-121.

Woolley, J. and Davis, J. H. C. 1991. The agronomy of intercropping with beans. In: Common beans: Research for crop improvement, van Schoonhoven, A. and Voyeset, O. (Eds.).CAB International in Association with CIAT, Wallingford, 707-735 pp.

\section{How to cite this article:}

Vidhyashree, R., M.B. Patil, A.K. Guggari and Biradar, A.P. 2019. Performance and Economics of Sweet Corn as Influenced by Leafy Vegetables Intercropping System under Protective Irrigated Condition. Int.J.Curr.Microbiol.App.Sci. 8(08): 865-871. doi: https://doi.org/10.20546/ijcmas.2019.808.100 